\title{
MENYIKAPI TANTANGAN DAN HARAPAN PENDIDIKAN AGAMA KRISTEN DALAM MASYARAKAT YANG MAJEMUK
}

\author{
Oleh: Ardianto Lahagu
}

\begin{abstract}
Abstrak: Manusia merupakan bagian dari masyarakat yang dituntut untuk selalu melakukan interaksi antara satu sama lainnya dalam hal pemenuhan kebutuhannya sebagai makhluk sosialmanusia merupakan bagian dari masyarakat yang dituntut untuk selalu melakukan interaksi antara satu sama lainnya dalam hal pemenuhan kebutuhannya sebagai makhluk sosial. Manusia dalam menjalankan kehidupannya akan membentuk suatu ikatan terkecil yang disebut keluarga. Menerapkan Pendidikan Agama Kristen di dalam keluarga, di sekolah, dan masyarakat sangatlah penting, tujuannya adalah agar terwujudnya keluarga terlebih-lebih masyarakat yang damai dan sejahtera dan tentram. Dalam realita kehidupan masyarakat masih banyak persoalan yang muncul dengan berbagai konflik yang terjadi yang seringkali dikaitkan dengan masalah suku, ras dan agama khususnya. Kehadiran Pendidikan agama Kristen di tengah-tengah masyarakat, khususnya yang majemuk adalah untuk melaksanakan amanat agung sebagaimana dalam Firman Allah. PAK bertujuan untuk dapat mewujudkan tujuan pendidikan nasional melalui peserta didik. Kehadiran PAK juga dapat menjadi alat pembentuk dan pemersatu bangsa di tengah masyarakat majemuk yang berbeda agama, suku, ras, golongan, dsb. Selain itu, kehadiran PAK dapat berperan serta untuk meningkatkan kualitas masyarakat Indonesia. Pendidikan Agama Kristen harus terus-menerus berkembang seiring dengan kemajuan zaman; memampukan manusia agar sadar terhadap keperbedaan dan keberagaman, mampu hidup bertoleransi, sadar terhadap iptek, kreatif, inovatif, serta memiliki solidaritas tinggi; peka terhadap konteks pendidikan nasional, pergumulan bangsa dan menjawab kebutuhan orang percaya.
\end{abstract}

Kata-kata Kunci:Pendidikan Agama Kristen, Masyarakat Majemuk 


\section{PENDAHULUAN}

Masyarakat di Indonesia terdiri dari berbagai suku, agama, ras, dan bangsa yang memilki latar belakang yang berbeda-beda baik dari segi kultur, letak geografis, maupun sikap dari masing-masing individu. Oleh karena itu, masyarakat Indonesia dikatakan masyarakat yang majemuk, namun, masyarakat Indonesia tetap memilki satu status dan kedudukan yang sama yakni sebagai masyarakat Indonesia yang memiliki hak dan kewajiban yang sama sebagai warga negara Indonesia, yang dituntut untuk selalu bersatu tanpa mempedulikan berbagai perbedaan yang ada demi menjaga keutuhan Negara Kesatuan Republik Indonesia.

Bila kita melihat sejarah perkembangan Pendidikan Agama Kristen (PAK), kita dapat melihat perubahan yang sering terjadi di dalam berbagai bentuk pelaksanaannya. Misalnya pada abad-abad pertengahan Pendidikan Agama Kristen didesain agar dapat diajarkan kepada orang yang baru saja menjadi Kristen dengan jumlah yang banyak. Maka metode untuk melaksanakan PAK ialah dengan menggunakan media seperti gambar-gambar, patung-patung yang digunakan sebagai saran PAK tersebut. Segi arsitektur bangunan gereja sangat penting sebagai sarana di dalam pelaksanaan PAK. Melalui arsitektur bangunan gereja inilah simbol dan ikon dalam kekristenan digunakan. Sherril menulis bagaimana sejarah seni bangunan gereja dapat melambangkan cerita 
perkembangan gereja itu sendiri."1

Demikian juga desain PAK dituntut perubahan sesuai dengan situasi dan kondisi yang ada. Abad reformasi hingga abad 21 memiliki konteksnya masing-masing. Inilah gambaran singkat, yang mungkin memberikan suatu kesadaran bagi kita saat ini dan di sini untuk melihat konteksnya masing-masing agar PAK mendapat tempat semestinya. PAK bukan sebagai produk import, tetapi PAK manjadi milik orang Asia dan secara khusus Indonesia.

Berikutnya akan kita lihat apa dan bagaimana konteks kita di sini sehingga PAK bisa diberikan dengan baik. Tentunya kontent (isinya) tidak begitu banyak perubahan, hanya konteksnya yang akan dilihat lebih jauh.

\section{TANTANGAN DAN HARAPAN PAK DALAM \\ MASYARAKAT MAJEMUK}

\section{Gambaran Sekilas Konteks PAK Dalam Beberapa Periode}

Pada abad-abad pertama: PAK diberikan secara "ketat" dari gereja kepada umat sebelum menjadi anggota sidi gereja, karena umat harus dilengkapi dengan ajaran yang benar agar tidak disesatkan. Dalam abad ke dua misalnya,

${ }^{1}$ Enklaar \& Homrighausen, Pendidikan Agama Kristen (Jakarta: BPK Gunung Mulia, 2011), 106. 
pendidikan gereja terhadap calon-calon untuk baptisan orang dewasa telah diatur dengan seksama. "Gereja menuntun supaya mereka belajar selama tiga tahun, baru mereka diuji dan diterima pada Baptisan dan Perjamuan Suci."2

Abad pertengahan: praktik PAK semakin merosot karena denominasi gereja yang lebih mementingkan "kristenisasi" ketimbang aspek pengajaran PAK itu sendiri. Pada masa ini gereja banyak mendidik melalui Sakramen Baptisan, Sakramen Misa, drama agamawi, seni lukis/patung dan juga melalui seni bangunan gereja. ${ }^{3}$

Abad reformasi: praktik PAK sangat diperhatikan oleh para reformator gereja. Sola Scriptura menjadi semboyan semangat untuk mengajarkan PAK secara baik dan benar, dan bukan dilakukan sebagai tradisi gereja. Masa ini diwakili oleh Luther dan Calvin. Luther menghasilkan karya yang berkaitan PAK yakni Katekismus. Luther mengaitkan pendidikan dengan teologi atau dengan kata lain teologinya merupakan dasar teori pendidikannya. Sedangkan Calvin menghasilkan karyanya Institutio, yaitu Pengajaran Agama Kristen yang merupakan teologi sistematis yang dengan jelas membela ajaran-ajaran Reformasi. Karya ini mengalami empat terbitan penting semasa hidup Calvin. Karyanya ini dapat membimbing seseorang dalam bimbingan teologi karena dilengkapi dengan penjelasan yang lebih lengkap mengenai pasal-pasal Alkitab.

${ }^{2}$ Robert Boehlke, Sejarah Perkembangan Pikiran Dan Praktek Pendidikan Agama Kristen I (Jakarta: BPK Gunung Mulia, 2011), 175.

${ }^{3}$ Lihat Boehlke, Sejarah Perkembangan Pikiran Dan Praktek Pendidikan Agama Kristenl, hal, 153-175. 
Abad 17-18: revolusi industri membuat PAK bergumul di dalam situasi ketidakadilan terhadap perlakuan manusia sebagai "mesin" pekerja, namun diupah tak sebanding (ex: Robert Raikers; pendiri Sekolah Minggu).

Abad 19: gerakan evangelikal dan revival berkembang. PAK pada masa ini dititikberatkan pada pertobatan manusia sebagai mausia berdosa. Inilah tema-tema yang terdapat dalam ibadah-ibadah KKR pada waktu itu. Lagu-lagunya pun dipilih berkisar tentang tema tersebut, misalnya Amazing Grace (KJ 40), dan Just As I Am (KJ 27).

Abad 20: gerakan ekumenis, PAK dititkberatkan pada hubungan oikumene, ketimbang sikap ekslusif masing-masing kelompok (ex: hubungan Kristen dan Katolik).

Dari gambaran di atas paling tidak menunjukkan dimana sekarang kita berada. Posisi kita sekarang berada di abad 21, yang mana masih kental dengan konteks hubungan oikumene dari abad ke 20. Secara khusus konteks Asia akan dibahas dalam tulisan ini, karena penggambaran konteks di atas semuanya lahir dari konteks Eropa dan Amerika. Penjelasan lebih lanjut akan dilihat nanti, tetapi sebelumnya perlu untuk merumuskan tentang defenisi konsep dari judul tulisan ini. 


\section{PAK dalam Masyarakat Majemuk}

Ada banyak defenisi mengenai PAK yang diberikan oleh para ahli PAK, namun di sini dibatasi dengan beberapa pandangan para ahli saja. Misalnya Horace Bushnell pengarang Christian Nurture, memberikan defenisi sebagai berikut: "Pendidikan Agama Kristen adalah pelayanan kegerejaan yang membimbing orangtua untuk memenuhi panggilannya sebagai orangtua Kristen, dan sekaligus memperlengkapi warga jemaat untuk hidup sebagai anggota persekutuan yang beribadah, bersaksi, mengajar, belajar dan melayani atas nama Yesus Kristus". ${ }^{4}$ Tentu saja Bushnell memberikan definisi demikian karena ia adalah seorang yang menekankan PAK dalam keluarga yang menuntut tanggung jawab orangtua di dalam mendidik anak.

Menurut Enklar dan Homrighausen, PAK berarti menerima pendidikan itu, segala pelajar, muda dan tua, memasuki persekutuan iman yang hidup dengan Tuhan sendiri, dan oleh dan dalam Dia mereka terhisap pula pada persekutuan jemaat-Nya yang mengakui dan mempermuliakan nama-Nya di segala waktu dan tempat". ${ }^{5}$

Menurut Calvin: PAK adalah pendidikan gereja yang mendewasakan umat Allah. Berkaitan dengan hal ini, Calvin mengutip tulisan Paulus dalam Efesus 4:10. ${ }^{6}$

${ }^{4}$ Boehlke, Sejarah Perkembangan Pikiran Dan Praktek Pendidikan Agama Kristen I, 501.

${ }^{5}$ Enklaar\&Homrighausen, Pendidikan Agama Kristen, 26.

${ }^{6} \mathrm{http}: / /$ eiren3s.blogspot.com/2013/10/pendidikan-agama-kristen-sebagai-tugas.html diakses pada tgl 3 Januari 2018. 
Dari definisi-definisi di atas kita dapat melihat perbedaannya masing-masing, karena setiap ahli mempunyai perspektif tersendiri. Bushnell memberikan definisi berkaitan dengan tanggung jawab orangtua dalam mendidik anak. Enklar dan Homrighausen memberikan definisi yang berkaitan dengan persekutuan. Sedangkan Calvin mengarahkannya lebih kepada pembinaan umat. Demikian dari ketiga definisi di atas, dapat dilihat begitu dinamisnya PAK. Mulai dalam keluarga, gereja, hingga masyarakat di segala waktu dan tempat.

Dalam tulisan ini, sedikit menantang kita untuk melihat PAK bukan dalam lingkup keluarga atau gereja, melainkan melihat dalam lingkup yang lebih jauh, yakni lingkup masyarakat. Masyarakat yang bagaimana? Masyarakat yang bukan homogen, melainkan heterogen. Bukan masyarakat Eropa atau Amerika, melainkan masyarakat Asia. PAK ditantang untuk melihat masyarakat yang serba majemuk dalam konteks Asia.

Ciri-ciri masyarakat majemuk:

1. Mempunyai struktur budaya lebih dari satu.

2. Nilai-nilai dasar yang merupakan kesepakatan bersama sulit berkembang.

3. Sering terjadi konflik-konflik sosial yang berbau SARA.

4. Struktur sosialnya lebih bersifat non komplementer.

5. Proses integrasi yang terjadi berlangsung secara lambat. 
6. Sering terjadi dominasi ekonomi, politik, dan sosial budaya. Prinsip-prinsip mengajar PAK dalam masyarakat majemuk harus memperhatikan :

a. Kemajemukan Budaya. PAK mesti memanfaatkan atau dilaksanakan dalam kebudayaan. Contoh: PAK melalui wayang, PAK melalui gondang, dsb.

b. Kemajemukan Bahasa. PAK mesti memanfaatkan keragaman bahasa bagi tersalurnya nilai-nilai Kristiani.

c. Kemajemukan suku. PAK tidak boleh membeda-bedakan suku.

d. Kemajemukan Agama. PAK mesti dilaksanakan secara pluralis, inklusif (terbuka) tetapi tetap mempertahankan nilai-nilai atau identitas Kristen, tetap melaksanakan misiTuhan.

\section{Konteks Asia}

Antone Hope, dalam bukunya Pendidikan Kristiani Kontekstual, memberikan banyak gambaran tentang PAK dalam konteks Asia. Untuk itu, pada pembahasan tentang konteks Asia, akan banyak dikutip dari buku tersebut.

Bila ada suatu kata yang dapat melukiskan dengan tepat wilayah di Asia, kata itu adalah pluralitas atau kemajemukan. Asia, benua dengan jumlah penduduk yang paling padat di dunia, merupakan wilayah di dunia yang sangat beragam dari 
segi budaya, bahasa, suku bangsa, dan agama. Kemajemukan budaya, bahasa, suku bangsa, dan agama seperti itu kadang terlihat sebagai sumber kesejahteraan dan kebanggaan. Namun, hal ini juga dilihat sebagai alasan untuk banyak konflik dan masalah. Memang, ada orang-orang Asia yang merasa bangga dengan karunia kemajemukan itu.

Namun, ada juga orang-orang yang mempersalahkan hal ini sebagai salah satu penyebab dari masalah intoleran, kebencian, dan kekerasan yang terus terjadi di wilayahnya. Namun, kemajemukan inilah yang menjadikan wilayah Asia seperti itu. Hal ini membuat Asia menjadi suatu konteks yang bukan monolitik, tetapi mungkin, lebih tepat sekelompok konteks geografis.

Dari berbagai kemajemukan yang saling berpaut di Asia, kemajemukan agama dan budaya menjadi realitas utama yang mencolok untuk dihadapi. Asia mempunyai populasi Muslim paling banyak, dengan Indonesia yang mempunyai populasi Muslim terbesar di antara semua negara di dunia. Asia juga mempunyai populasi terbesar dari penganut Budha, Taoisme, dan Hinduisme. Kekristenan adalah agama minoritas di seluruh wilayah Asia, kecuali di Filipina di mana agama ini menjadi agama yang paling banyak dianut.

Realitas lain dari konteks Asia adalah persoalan kemiskinan, perjuangan, dan penderitaan. Sering dikatakan bahwa pada masa kini, kecuali kematian yang diakibatkan oleh bencana alam, yang sekarang dan kemudian terjadi, lebih 
banyak orang mati karena konflik agama dan suku daripada karena kelaparan atau penyakit. Bagaimanapun, akar konflik agama dan etnis ini seringkali sungguh-sungguh disebabkan oleh karena ketidakadilan sosial-ekonomi dan politik. ${ }^{7}$

\section{Tantangan \& Harapan}

Jika konteks Asia sudah kita lihat di atas, menjadi pertanyaannya apa dan bagaimana yang harus dilakukan PAK di dalam konteks Asia yang demikian. Konteks ini merupakan suatu tantangan tetapi juga sekaligus harapan.

\section{Tantangan}

Menurut KBBI. ${ }^{8}$ Tantangan berarti: (1) ajakan berkelahi, (berperang dsb); (2) hal atau objek yang menggungah tekad untuk meningkatkan kemampuan untuk mengatasi masalah; rangsangan (untuk bekerja lebih giat); (3) hal atau objek yang perlu ditanggulangi. Dari definisi tersebut, barangkali definisi kedua yang lebih cocok untuk melihat pergumulan PAK dalam konteks Asia ini.

Kemajemukan merupakan suatu tantangan tersendiri bagi masyarakat Asia yang multikultural ini. Berbeda dengan konteks Eropa dan Amerika yang sudah kita lihat di depan. Apa yang ingin dilakukan PAK dalam masyarakat plural seperti

${ }^{7}$ Antone Hope, Pendidikan Kristiani Kontekstual, 2010, 2-4

${ }^{8} \mathrm{http}: / /$ kamusbahasaindonesia.org/tantangandiakses pada 8 Januari 2018. 
ini, dan bagaimana melakukannya? Paling tidak masalah yang dihadapi PAK dan juga teologi hampir sama di dalam melihat konteks Asia. Jika di dalam teologi, banyak tokohtokoh teolog Asia seperti C.S Song, Ariarajah, Kung dsb, yang telah mencoba menggali kearifan lokal dari kebudayaan Asia untuk bisa dijadikan bahan berteologi dalam konteks Asia. Maka PAK pun harus meramu bahannya sendiri untuk bisa dikonsumsi di masyarakat Asia.

Telah berabad-abad kita mengadopsi pemikiran Barat dan diterapkan dalam masyarakat Asia tanpa melihat konteksnya baik dalam teologi maupun PAK. Inilah tantangan dari PAK untuk menjawab pergumulan masyarakat Asia sekarang. Dengan melihat konteks kemajemukan serta konflik agama yang banyak terjadi di masyarakat Asia, barangkali perlu dicari suatu model desain PAK yang lain agar bisa menjawab konteks Asia.

Banyak pemikir PAKAsia yang menawarkan pendidikan untuk kedamaian (education for peace). Salah satu tokoh di antaranya ialah Kim Yong Bock. Menurut Kim Yong Bock, Tujuan pendidikan Asia adalah komunitas keadilan, perdamaian, kerja sama dan rekonsiliasi. Mengakui sistem sekolah dan media massa tidak hanya korban tetapi juga promotor dari proses globalisasi, kita harus mengadopsi lahan baru, pendidikan untuk keadilan, perdamaian dan kehidupan (education for justice, peace and life) .

Tokoh lainnya yaitu Sugirtharajah. ${ }^{9}$ mengatakan:

${ }^{9}$ Antone, Pendidikan Kristiani Kontekstual,2010, 86. 
"pendekatan dialogis adalah suatu pendekatan yang mengakui keabsahan pengalaman keagamaan yang berbeda dan beragam dari semua orang dan menyingkirkan semua klaim eksklusif terhadap kebenaran satu tradisi agama. Dalam pendekatan ini, setiap agama patut dikasihi dan dihargai. Semua agama mengandung unsur pembebasan dan juga unsur penindasan, sementara tugas hermeneutika adalah mengumpulkan aspek-aspek yang membebaskan untuk menciptakan harmoni dan perubahan sosial bagi semua orang".

Barangkali inilah suatu tantangan yang harus dihadapi. PAK bukan hanya mengajarkan tentang doktrin/dogma semata, tetapi juga memiliki tujuan dalam pelaksanaannya dalam konteks Asia ini. Education for peace perlu menjadi tujuan dalam pelaksanaan PAK di Asia yang majemuk, karena dari kemajemukan tersebut sering terjadi juga banyak konflik.

\section{Harapan}

Menurut KBBI, Harapan adalah: (1) sesuatu yang (dapat) diharapkan; (2) keinginan supaya menjadi kenyataan; (3) orang yang diharapkan atau dapat dipercaya. ${ }^{10}$

Dengan kata lain harapan adalah kemampuan untuk menarik masa depan ke masa kini, sehingga dapat menembus keputusasaan dan jalan buntu. Jika demikian apa yang menjadi harapan PAK dalam masyarakat Asia? Paling

${ }^{10}$ (http://kamusbahasaindonesia.org/harapan)diakses pada 8 Januari 2015. 
tidak kita menaruh harapan bersama yaitu kehidupan yang penuh dengan keadilan dan kedamaian. Sebagaimana Yesus yang membawa harapan kepada mereka yang tersisih berupa kedamaian. Kedamaian kepada perempuan Siro-Fenesia, kedamaian kepada permpuan Samaria, kedamaian kepada Zakheus yang dimusuhi, kedamaian kepada perempuan yang didapati berzinah. Yesus memberi teladan yang luar biasa bagi mereka yang tersisih pada zaman la hidup, dan dengan demikian mereka dapat mengenal Allah lewat perbuatan Yesus.

Semua yang dilakukan Yesus bukan berarti Yesus tidak mendapat tantangan. Justru, karena la melihat harapan yang besar agar orang dapat mengenalAllah maka segala tantangan mau dihadapinya. la ditantang untuk merangkul kaum perempuaan pada waktu itu yang dianggap tidak sederajat dengan laki-laki. la merangkul orang-orang non-Yahudi yang dianggap tidak mendapati karya keselamatan Allah. la juga merangkul Zakheus yang dimusuhi oleh masyarakat sekitar karena dianggap sebagai pemeras. Rangkulan Kristus membawa keadilan dan membuat kita merasa damai.

PAK dalam konteks Asia pun semestinya meneladani Kristus di dalam merangkul semua lapisan masyarakat. PAK Asia semestinya tidak lagi alergi dengan agama lain atau budaya yang lain. Justru tantangan itulah yang perlu dihadapi. Tantangan itu perlu dilihat sebagai sarana untuk pendidikan cinta kasih yang membebaskan. PAK Asia hendaknya tidak 
hanya menekankan pada doktrin atau dogma gereja saja, tetapi juga perlu untuk melihat sampai kepada mereka yang membutuhkan. Tantangan yang dihadapi PAK dalam masyarakat majemuk ini perlu melihat ke depan akan harapan yang ada. Dengan demikian harapan tersebut bisa menjadi berkat bagi PAK itu sendiri. Barangkali kita perlu melihat refleksi dari Lesslie Newbegin. ${ }^{11}$ yang melihat tantangan sebagai suatu berkat jika dihadapi.

Dalam buku ini Lesslie Newbigin melihat bahwa kenyataan adanya sekian banyak agama, dogma dan budaya merupakan tantangan dan sekaligus menjadi berkat bagi umat Kristen. Tantangan yang dimaksudkannya pertamatama terungkap dalam pertanyaan, mengapa ada begitu banyak agama, dogma dan budaya? Mengapa ada begitu banyak orang yang bertemu dengan Allah di luar Kristus dan kekristenan? Tantangan-tantangan tersebut menjadi lebih dalam dan menyakitkan apabila pertanyaan-pertanyaan itu ditinjau di bawah terang hakekat dan tuntutan-tuntutan pluralisme unitif.

Bagi Lesslie Newbigin, pluralisme agama justru merupakan kairos bagi kekristenan. Dengan kairos ini kekristenan ditawari kesempatan bagi terjadinya pertumbuhan tulen dan evolusi, serta untuk memahami sekali lagi amanat Injil, dalam satu cara dimana kekuatan Injil dapat lagi bersinar dalam cara yang segar dan dalam bentuk yang lebih dapat

${ }^{11}$ Newbigin Lesslie, Injil Dalam Masyarakat Majemuk (Jakarta: BPK Gunung Mulia, 2002). Lihat pembahasan khusus mengenai Tantangan \& Berkat. 
dipahami. Menurut Lesslie Newbigin, kehilangan kesempatan ini sama artinya dengan menempatkan sinar Injil di bawah gantang sehingga membuat kabar baik itu menjadi lebih sulit dipercayai.

Lesslie Newbigin sangat menekankan tentang Injil dan tradisi Kristen. Sepanjang sejarahnya, kekristenan senantiasa tergantung pada konteks sejarah yang selalu berubah. Lesslie Newbigin juga membuktikan kebenaran pendapatnya ini dengan menunjuk sejarah gereja. Ketika jemaat pertama berpindah dari konteks kebudayaannya yang pertama, yaitu dari Yudaisme ke dunia Romawi-Yunani, mereka mengalami transformasi yang sangat jauh. Transformasi yang dimaksud bukan saja dalam kehidupan liturgis dan sakramental geraja serta struktur organisasi dan legislasinya, tetapi juga dalam doktrin yaitu dalam pemahamannya akan penyataan yang telah melahirkannya.

Lesslie Newbigin yakin bahwa gereja Kristen dalam menghadapi dunia pluralisme agama dan dialog antar agama, memungkinkannya mengalami suatu kairos dengan satu janji terjadinya transformasi diri, tidak berada di luar garis sejarah.

Hal-hal yang harus mulai dilakukan oleh dunia pendidikan dalam kemajemukan masyarakat Indonesia adalah: 


\section{Belajar Hidup Dalam Perbedaan}

Pengembangan sikap toleran, empati, dan simpati haruslah terus dibangun sebagai prasyarat eksistensi keragaman agama yang ada. Selama ini pola pendidikan di Indonesia bersandar pada tiga pilar utama yaitu: Learning To Know, Learning To Do, Learning To Be. Dalam kaitan dengan heterogenitas agama-agama di indonesia maka sangat penting dibangun pilar ke empat yaitu Learning to live together. Dengan demikian peserta didik lewat proses belajarnya dimampukan hidup bersama dengan orang lain yang memiliki latar belakang hidup yang berbeda.

Toleransi adalah kesiapan dan kemampuan batin untuk kerasan bersama dengan orang lain yang berbeda secara hakiki, meskipun dalam cara hidup dan keyakinan terdapat konflik dalam hidup tentang apa yang baik dan buruk. Toleransi memerlukan dialog untuk mengkomunikasikan dan menjelaskan perbedaan, menuntut keterbukaan, dan menerima perbedaan itu sebagai realitas hidup. Dalam konteks Indonesia sekarang ini, menerima perbedaan harus ditanamkan lewat berbagai jalur kehidupan seperti, jalur pendidikan formal dan non formal. Dunia pendidikan haruslah memasyarakatkannya dengan sungguh-sungguh kepada seluruh lapisan masyarakat. 


\section{Membangun Sikap Saling Percaya}

Membangun sikap saling percaya adalah modal penting dalam membangun suatu masyarakat yang heterogenitas. Jika tidak maka akan terjadi berbagai konlik dalam masyarakat.Pembangunan hidup masyarakat suatu bangsa yang heterogenitas seperti Indonesia tidak akan terjadi tanpa ada saling percaya diantara kelompok-kelompok masyarakat yang berbeda dalam agama maupun suku. Perbedaan tidak dapat dijadikan menjadi potensi atau kekuatan bangsa, melainkan dapat menjadi malapetaka yang mengakibatkan kehancuran suatu bangsa. Saling percaya adalah pondasi bagi terbangunnya sikap rasional, tidak mudah curiga, bebas dari prasangka buruk.

\section{Memelihara Saling Pengertian}

Saling pengertian bukan berarti menyetujui perbedaan, banyak orang tidak mau memahami atau mengerti penganut keyakinan lain, sebab ia dapat dituduh sebagai orang yang menyetujui keyakinan lain tersebut atau bersifat kompromi terhadap perbedaan yang ada. Saling pengertian adalah kesadaran bahwa nilai-nilai yang dianut oleh orang lain memang berbeda,tetapi mungkin dapat saling melengkapi dengan nilai-nilai yang kita anut serta memberi kontribusi 
terhadap hubungan yang harmonis. Saling pengertian dapat saling melengkapi dan memungkinkan dibangunnya kerjasama yang baik. Saling pengertian adalah rasa percaya bahwa penganut agama lain tidak akan melakukan usahausaha yang tidak baik, untuk mempengaruhi,mengajak atau memberi dorongan agar ia berpindah pada apa yang kita yakini. Pendidikan agama mempunyai tanggungjawab membangun landasan etis kepedulian terhadap sesama dan menghindari kesalahpahaman.

\section{Sikap Saling Menghargai}

Sikap saling menghargai adalah menjunjung tinggi harkat dan martabat kesetaraan. Menghargai sesama manusia adalah sifat dasar yang diajarkan semua agama. Menjaga kehormatan diri bukan berarti harus mengorbankan atau mengalahkan harga diri orang lain. Saling menghargai adalah sifat dasariah manusia. Setiap manusia haruslah dihargai sebagaimana ia ada. Tidak ada alasan bagi kita untuk tidak menghargai orang lain.Yesus memberikan Teladan bagi kita bagaimana la sebagai Tuhan dan Juruselamat memberi penghargaan yang tulus kepada kita. la menerima kita sebagaimana kita ada.Yesus tidak pernah mempersoalkan latarbelakang golongan kita,atau warna kulit kita.la mengasihi semua orang dan mengorbankan diri-Nya untuk semua orang. 
Yesus menghargai Zakheus pemungut cukai dan menghargai perempuan pelacur yang dianggap hina oleh masyarakat. Yesus menghargai orang lumpuh di kolam Bethesda dan menghargai perempuan Samaria yang bertemu dengannya di sumur Yakub. la juga menghargai anak-anak kecil dan menghargai orang-orang tua yang sudah tidak berdaya.

Sikap saling menghargai antar penganut agamaagama, dan memungkinkan kita dapat dan siap mendengarkan sura agama lain yang berbeda,menghargai martabat setiap individu dan kelompok keagamaan yang beragam. Saling menghargai akan membawa pada sikap saling berbagi di antara semua individu.

\section{KESIMPULAN DAN SARAN}

Setiap zaman mempunyai tantangannya tersendiri. Kita perlu belajar dari kisah hidup Yesus yang mampu menghadapi tantangan karena mampu melihat harapan, dan lebih dari itu ialah berkat. Dengan melihat konteks Asia yang serba majemuk dan juga jumlah komunitas Kristen yang kecil dibanding agama-agama lain, PAK tidak harus menjadi pesimis. Justru dengan inilah PAK ditantang untuk melihat harapan dan juga berkat yang ada di depan. Bersentuhan dengan agama dan juga budaya lain tidak harus membuat PAK bersifat eksklusif melainkan meliahatnya sebagai kairos 
seperti yang diungkapkan Lesslie Newbigin.

Adapun saran yang diberikan dalam tulisan ini adalah:

Pertama, tantangan konteks Asia ini membuat PAK agar mampu membawa pendidikan untuk kedamaian (education for peace) bagi segala lapisan masyrakat.

Kedua, sikap-sikap eksklusif perlu dipertimbangkan kembali karena itu tidak selalu membawa berkat bagi masyarakat yang lain melainkan konflik yang terjadi.

Ketiga, mengingat Asia banyak sekali budayanya, maka PAK Asia hendaknya melihat kearifan lokal masing-masing agar dapat mendesain bahan PAK yang menjadi ciri khas tersendiri dan bukan PAK produk Eropa atau Amerika. 


\section{Daftar Pustaka}

Boehlke, Robert. Sejarah Perkembangan Pikiran Dan Praktek Pendidikan Agama Kristen Jilid I \& II, Jakarta : BPK Gunung Mulia, 2011.

Christian Conference Of Asia. Religion Education In Asia. Hong Kong, 2003.

Enklar \& Homrighausen. Pendidikan Agama Kristen. Jakarta: BPK Gunung Mulia, 2011.

Groome, Thomas. Christian Religious Education. Jakarta: BPK Gunung Mulia, 2011.

Hope, Antone. Pendidikan Kristiani Kontekstual. Jakarta: BPK Gunung Mulia, 2010.

Newbigin, Lesslie. Injil Dalam Masyarakat Majemuk, Jakarta: BPK Gunung Mulia, 2002.

http://eiren3s.blogspot.com/2013/10/pendidikan-agama-kristen-sebagai-tugas.html (website)

http://kamusbahasaindonesia.org

\section{TENTANG PENULIS}

Ardianto Lahagu adalah dosen tetap di STT Real Batam. Kini ia membantu departemen R \& D di lembaga tersebut. 